\title{
Evaluasi Materi Ajar Bahasa Inggris Cambridge IGCSE dan A/AS Level Sebagai Materi Acuan Program SBI tingkat SMA di Indonesia, Studi Kasus SMAN 70 Jakarta
}

\author{
Ria Herwandar ${ }^{1 *}$ Amelia Iswandari ${ }^{2}$, Muhammad Iqbal $^{3}$ \\ ${ }^{1,2,3)}$ Fakultas Sastra, Universitas Al Azhar Indonesia, Jl. Sisingamangaraja, Jakarta 12110 \\ Tel. 7244456, Faks. 7244767, ${ }^{*}$ email ria herwandars@uai.ac.id
}

\begin{abstract}
A law no 20/2000 paragraph 50, article 3 has been enacted by the Ministry of education concerning the implementation of International class in high Schools throughout Indonesia. The purpose of this regulation is to standardize the quality of the Indonesian students educational qualification to those of students abroad. As a result, Cambridge International Examinations IGCSE, A/AS Level have become popular to the majority of Indonesian High Schools, especially for subjects such as Mathematics, English, Physics, Biology and Chemistry. This research will look upon the develompment of school implementation of IGCSE, A/AS Level of English Language in SMA $N 70$ jakarta as a case study. Through several assessments of students IGCSE, A/AS Level tests, interviews, questionners and material evaluation, a reliable findings will be identified. At the end, ways of effective learning and teaching of IGCSE, A/AS Level for Indonesian High Schools will be suggested.
\end{abstract}

Keywords - Cambridge International Examinations IGCSE, A/AS Level

\section{PENDAHULUAN}

$\mathrm{P}$ enelitian ini berkaitan dengan penelitian sebelumnya yang berjudul "Tingkat Kesulitan Materi ajar Bahasa Inggris Cambridge IGCSE, A/AS Level Bagi Siswa Sekolah Bertaraf Internasional (SBI) Sekolah Menegah Atas“. Penelitian dalam judul tersebut mengungkapkan secara umum mengenai Tingkat kesulitan materi ajar Cambridge. Dalam penelitian saat ini merupakan penelitian yang terfokus pada siswa sekolah SMAN 70 dalam melaksanakan pembelajaran Bahasa Inggris Cambridge IGCSE,
A/AS Level. Disini akan terlihat bagaimana para siswa tumbuh kembang mengikuti program yang dicanangkan oleh Departemen Pendidikan terkait program SBI.

Di Indonesia, Cambridge International Examinations. IGCSE, A/AS Level menjadi pilihan bagi banyak sekolah swasta dan terutama sekolah negeri yang mendapat hibah dari Departemen Pendidikan seperti SMAN 70 yang menerapkan pola pendidikan yang diselenggarakan Inggris Melalui institusi Cambridge International Examinations.

Di Inggris, IGCSE diperuntukkan bagi murid sekolah SMP kelas 3 dan SMA kelas 1, sementara kelas 2 dan 3 masuk kedalam tingkat A/AS Level Kesenjangan yang terjadi dari pendidikan pada Level IGCSE ke A/AS Level menjadi suatu masalah untuk diselidiki. Dalam mengevaluasi materi ajar Cambridge ini, murid SMAN 70dipilih sebagai studi kasusIGCSE dan A/AS Level,

\section{METODOLOGI PENELITIAN (KUALITATIF) DAN TEKNIK PENGUMPULAN DATA}

Mc Millan \& Schumachter dalam (Syamsuddin \& Damaianti, 2006:73), mendefinisikan bahwa penelitian kualitatif merupakan suatu pendekatan investigasi karena biasanya peneliti mengumpulkan data dengan bertatap muka langsung dan berinteraksi dengan orang-orang di tempat penelitian.

Pendekatan pada penelitian kualitatif ini melibatkan pendekatan studi kasus karena memang dalam penelitian sering dikaitkan dengan penelitian kualitatif demikian pendapat Bogdan dan Biklen juga Burges dalam (Syamsuddin \&Damaianti, 2006:178). Dalam keseluruhan proses penelitian pendidikan bahasa, Kerangka pendekatannya menggunakan pendekatan 'Assessment'. Karena 
pada keseluruhan tahapan proses penelitian, semuanya mencerminkan dan melibatkan kegiatan'on-going assessment.

Sumber data terdiri dari 1 kelas pelajar program internasional kelas 2 SMAN 70 Jakarta Kebayoran Baru . Jumlah murid terdiri dari 23 orang, 8 orang laki-laki dan 15 perempuan. Umur antara 15-17 tahun dengan gabungan siswa IPS dan IPA.

\section{TEMUAN DAN ANALISIS}

Materi yang akan dibahas adalah hasil ujian IGCSE siswa berdasarkan assessment, diikuti dengan analisis; hasil ujian A/AS Level English Language; kuesioner siswa terhadap IGCSE, A/AS Level; wawancara tertulis terhadap guru kelas siswa; dan temuan dan analisis perbandingan materi IGCSE dan A/AS Level.

\subsection{IGCSE assessment dan Hasil Ujian}

Cambridge IGCSE English as a Second Language dibagi menjadi Core curriculum dan Extended Curriculum. Siswa diberi kebebasan untuk memilih salah satu dari kedua jenis IGCSE. Dalam core curriculum kelulusan siswa dinilai dengan rentang nilai dari $\mathrm{C}$ sampai dengan $\mathrm{G}$. Secara keseluruhan core curriculum lebih mudah karena tugas yang dikerjakan lebih sedikit dibandingkan dengan extended curriculum.

Dalam extended curriculum kelulusan siswa dinilai dengan rentang nilai dari A sampai $\mathrm{E}$ saja dan materi extended adalah materi core ditambah beberapa materi lain yang menjadikan ujian ini menjadi extended yang berarti kelanjutan dari yang core. Ke dua jenis ujian IGCSE ini menyediakan materi uji dalam Reading, writing, Speaking dan Listening. Nilai ujian IGCSE yang diperoleh para siswa SMA 70 adalah nilai ujian IGCSE Extended Curriculum. Dengan demikian, Berdasarkan informasi dari University of Cambridge International Examinations Assessment objective untuk Core dan Extended curriculum adalah Reading/Writing, Speaking dan Listening.
3.1.1. Assessment Objective Core and Extended Curriculum IGCSE. (Tabel 1)

Reading: Semua peserta harus mampu :

- Mendemonstrasikan kemampuan mencerna text untuk publik seperti iklan, jadwal transportasi.

- Merangkum informasi dari beragam sumber seperti surat, brosur, penulisan imaginative;

- Mengidentifikasi dan mengolah spesifik informasi

- Menyaring informasi penting dari beragam teks

- Mengidentifikasi tema dalam teks yang lebih komplek/extended

- Menarik simpulan pada teks extended

Writing: Semua peserta harus mampu:

- Menulis tugas penulisan sederhana, seperti mengisi formulir,menulis kartu pos, surat dengan format penulisan bahasa Inggris yang benar dan lugas sebagai respon terhadap suatu stimulus;

- Menjabarkan, melaporkan dan memberi informasi pribadi dalam tulisan

- Mencari, mengorganisasi dan menuliskan dalam format yang sesuai

- Merespon pertanyaan dari tulisan yang lebih panjang dari topic yang luas

Listening: Semua peserta harus mampu:

- Menangkap informasi mengenai pengumuman yang formal seperti berita, cuaca,wawancara.

- Mengidentifikasi tema dan sikap penulis;

- Mengambil kesimpulan dan mengidentifikasi hubungan antara ide dari materi yang didengar

- Mengerti dan mencatat ragam register.

Speaking: semua peserta harus mampu:

- Berbicara dalam beragam kegiatan percakapan seperti menjawab pertanyaan tentang topic yang beragam tentang masa lampau, sekarang dan masa depan secara berkesinambungan;

- Fleksibel menanggapi gagasan/ide topic yan baru (Terjemahan dari IGCSE Assessment)

\subsubsection{Penjabaran nilai IGCSE grade A -F}

Para peserta ujian SMAN 70 mampu mencapai kemahiran dalam Speaking, writing, Reading dan Listening. Nilai A-C diharuskan mampu mengembangkan materi/pengalaman dengan lugas, relevan, terstruktur dan mencerminkan komunikasi yang baik. Untuk nilai D-F paling tidak mampu mencerminkan alur pembuka, isi dan penutup dilengkapi tata bahasa dan kosa kata yang cukup baik. 
3.1.3. Hasil ujian IGCSE Juni 2009 berdasarkan pilihan silabus dan komponen (Tabel 2)

\begin{tabular}{|c|c|c|c|c|c|}
\hline & Nama peserta & $\begin{array}{l}\text { Hasil } \\
\text { Ujian }\end{array}$ & $\begin{array}{c}04 \\
30 \% \\
\end{array}$ & $\begin{array}{c}05 \\
\mathrm{~s}\end{array}$ & $\begin{array}{c}22 \\
70 \% \\
\end{array}$ \\
\hline & Adji Karlita S & B & A & A & B \\
\hline 2. & Adyaksa Adha R & B & A & A & $\mathrm{C}$ \\
\hline 3. & Alianda B. R. & $\mathrm{C}$ & B & A & $\mathrm{C}$ \\
\hline 4. & Amira dewi D & $\mathrm{C}$ & B & A & $\mathrm{C}$ \\
\hline 5. & Amanda Cyko P & $\mathrm{U}$ & $\mathrm{U}$ & B & $\mathrm{U}$ \\
\hline 6. & Antia Savira & A & A & * & B \\
\hline 7. & Audria marjani $\mathrm{P}$ & $\mathrm{D}$ & $\mathrm{D}$ & A & $\mathrm{D}$ \\
\hline 8. & AyudiahSafitri & $\mathrm{C}$ & B & A & $\mathrm{C}$ \\
\hline & Carissa andhini $\mathrm{P}$ & $\mathrm{C}$ & A & A & $\mathrm{C}$ \\
\hline 10. & Elmo Tuwaidan & $\mathrm{C}$ & A & A & $\mathrm{D}$ \\
\hline 11. & EvanGilbert & $\mathrm{C}$ & B & A & $\mathrm{D}$ \\
\hline 12. & Heidi Asmarani & $\mathrm{D}$ & $\mathrm{D}$ & A & $\mathrm{D}$ \\
\hline 13. & Immanuel Partogi & $\mathrm{C}$ & B & B & $\mathrm{C}$ \\
\hline 14. & Kevin Muhammad & $\mathrm{C}$ & B & B & $\mathrm{C}$ \\
\hline 15. & Maximilian Gala & B & $\mathrm{C}$ & A & B \\
\hline 16. & Muhammad.K. & B & A & $\mathrm{C}$ & $\mathrm{C}$ \\
\hline 17. & Mutia.DP & $\mathrm{D}$ & $\mathrm{D}$ & A & $\mathrm{D}$ \\
\hline 18. & Pricillia justian & $\mathrm{D}$ & B & A & $\mathrm{E}$ \\
\hline 19. & Radifan.W. & $\mathrm{D}$ & $\mathrm{D}$ & A & $\mathrm{E}$ \\
\hline 20. & Ramsey.R. & $\mathrm{A}^{*}$ & A & A & A \\
\hline 21. & Riola Tantri D & $\mathrm{D}$ & $\mathrm{D}$ & B & $\mathrm{D}$ \\
\hline 22. & Rizki Imansari S & B & B & A & B \\
\hline 23. & Tanya Nabila & B & A & $*$ & B \\
\hline
\end{tabular}

Tabel diatas memperlihatkan bahwa secara keseluruhan para peserta ujian IGCSE siswa pelajar SMA 70 Jakarta telah berhasil melalui persyaratan tingkat kesulitan bahasa pada tingkat IGCSE. Seperti tercermin dalam criteria penilaian, Nilai IGCSE yang tertinggi adalah A sampai dengan F. Dibawah $F$ adalah Ungraded. Nilai tertinggi dicapai oleh peserta bernama Ramsey Reyswan OJ dengan nilai $A^{*}$ yang berarti siswa ini mendapat nilai $\mathrm{A}$ pada ketiga komponen yang di ujikan. Nilai A diraih juga oleh Anita Savira. Dengan kata lain kemampuan ke dua siswa mengerti dan mampu menjabarkan argumentasi, gagasan dan informasi secara tepat sasaran dan mencerminkan tingkat kemampuan bahasa yang baik. Dari 23 siswa yang mengikuti ujian, hanya 1 siswa bernama Amanda Cyko mendapat nilai Ungraded atau tidak ada nilai karena tiak memenuhi kriteria.

\subsection{A/AS Level Assesment Of Student Exam papers}

Siswa telah diberikan ujian A/AS Level. Penilaian hasil karya mereka berdasarkan Mark scheme bulan October/ November 2009. Paper ujian dinamakan English Language paper 1 Passage for Comment dengan code 8693/12 dan paper 2. Composition dengan code 8693/21

\subsubsection{Assessment Objectives}

Mark Scheme sangat erat berkaitan dengan Assessment Objectives dari pengajaran. Dengan demikian sebelum menganalisis Mark Scheme, Assessment Objectives dalam proses pembelajaran perlu diketahui dan dibawah ini adalah criteria Assessment Objectives dari A/AS Level paper 1 dan paper 2. Siswa diharapkan memiliki kemampuan untuk membaca dan memahami materi tulisan atau wacana dalam berbagai bentuk atau genre, dan mampu memberi tanggapan atau ulasan mengenai kelugasan dan ketepatan teks. Siswa harus memiliki wawasan, pemahaman akan ciri-ciri (features) bahasa Inggris dan mampu menulis untuk tujuan tertentu kepada pembaca tertentu dengan jelas, tepat dan lugas.

Dalam ujian, setiap jawaban diberi nilai tertinggi 25 dalam paper $2 / 21$ dan paper $1 / 12$ adalah :

3.2.2. Mark Scheme -GCE A/AS LevelOctober/November 2009. Syllabus 8693 Paper 12. Part (A)- Commentary (Tabel 3)

\begin{tabular}{|c|c|c|c|}
\hline & $\begin{array}{l}\text { Kemahiran } \\
\text { \&Pemahaman }\end{array}$ & $\begin{array}{l}\text { Dampak Analisis } \\
\text { Bahasa }\end{array}$ & $\begin{array}{l}\text { Pengorgan } \\
\text { isa sian }\end{array}$ \\
\hline $\begin{array}{l}\text { Band } \\
1 \\
13- \\
15\end{array}$ & $\begin{array}{l}\text { Tajam } \\
\text { mengapresiasi } \\
\text { isi dan ide. } \\
\text { Mahir } \\
\text { mengaitkan isi. }\end{array}$ & $\begin{array}{l}\text { Menganalisis } \\
\text { text dengan } \\
\text { tajam. }\end{array}$ & $\begin{array}{l}\text { Penguasa } \\
\text { an struktur } \\
\text { yang kuat } \\
\text { dan lugas. }\end{array}$ \\
\hline $\begin{array}{l}\text { Band } \\
2 \\
10- \\
12\end{array}$ & $\begin{array}{l}\text { konsistensi } \\
\text { mengapresiasi } \\
\text { isi dan ide } \\
\text { text; } \\
\text { mengaitkan isi } \\
\text { dengan } \\
\text { struktur, } \\
\text { pembaca, } \\
\text { tujuan, genre, } \\
\text { gaya wacana }\end{array}$ & $\begin{array}{l}\text { Menganalisis } \\
\text { teks, } \\
\text { peka pada } \\
\text { dampak, meng- } \\
\text { aitkan bagian } \\
\text { teks pada } \\
\text { keseluruhan } \\
\text { wacana pada saat } \\
\text { mendiskusikan } \\
\text { pemakaian } \\
\text { bahasa tertentu. }\end{array}$ & $\begin{array}{l}\text { Penguasa } \\
\text { an struktur } \\
\text { yang kuat, } \\
\text { argument } \\
\text { jelas. }\end{array}$ \\
\hline $\begin{array}{l}\text { Band } \\
3 \\
8-9\end{array}$ & $\begin{array}{l}\text { Isi /ide } \\
\text { gagasan stabil; } \\
\text { adanya } \\
\text { pemahaman } \\
\text { struktur, } \\
\text { pembaca,tujua } \\
\text { n, genre, gaya } \\
\text { bahasa teks }\end{array}$ & $\begin{array}{l}\text { Analisis teks } \\
\text { menyeluruh, } \\
\text { Mengidentifika- } \\
\text { si fitur bahasa, } \\
\text { memberi contoh, } \\
\text { menjelaskan } \\
\text { dampak pada } \\
\text { wacana }\end{array}$ & $\begin{array}{l}\text { Struktur } \\
\text { jelas,focus }\end{array}$ \\
\hline $\begin{array}{l}\text { Band } \\
4 \\
6-7\end{array}$ & $\begin{array}{l}\text { Ada isi/ide } \\
\text { gagasan; } \\
\text { pengertian } \\
\text { secara umum } \\
\text { atas struktur, } \\
\text { tujuan,genre, } \\
\text { pembaca,gaya } \\
\text { wacana }\end{array}$ & $\begin{array}{l}\text { Menjabarkan } \\
\text { beberapa } \\
\text { point.contoh } \\
\text { dengan benar, } \\
\text { mengidentifikasi } \\
\text { beberapa fitur } \\
\text { bahasa, menjelas } \\
\text { kan effek yang } \\
\text { terbentuk, } \\
\text { mungkin ada } \\
\text { penjelasan } \\
\text { sebagian wacana }\end{array}$ & $\begin{array}{l}\text { Pemapa } \\
\text { ran } \\
\text { struktur } \\
\text { yang jelas; } \\
\text { mungkin } \\
\text { dalam } \\
\text { baris baris } \\
\text { kalimat; } \\
\text { esai yang } \\
\text { diciptakan } \\
\text { tidak } \\
\text { terlalu } \\
\text { focus }\end{array}$ \\
\hline
\end{tabular}




\begin{tabular}{|c|c|c|c|}
\hline $\begin{array}{l}\text { Band } \\
5 \\
3-5\end{array}$ & $\begin{array}{l}\text { Beberapa point } \\
\text { yang terkait } \\
\text { dengan isi } \\
\text { wacan;bebera- } \\
\text { pa pemahaman } \\
\text { struktur } \\
\text { umum, } \\
\text { pembaca, } \\
\text { tujuan, genre, } \\
\text { gaya bahasa } \\
\text { teks;terlihat } \\
\text { beberapa } \\
\text { kesalahan } \\
\text { dalam } \\
\text { mengidentifi- } \\
\text { kasi kunci } \\
\text { character }\end{array}$ & $\begin{array}{l}\text { Beberapa point } \\
\text { terkait, contoh } \\
\text { terbatas ada } \\
\text { penggunaan } \\
\text { bahasa; ada } \\
\text { contoh yang } \\
\text { tidak relevan atas } \\
\text { dampak; } \\
\text { beberapa contoh } \\
\text { diberikan tanpa } \\
\text { penjelasan; lebih } \\
\text { merupakan suatu } \\
\text { generalisasi }\end{array}$ & $\begin{array}{l}\text { Sedikit } \\
\text { struktur; } \\
\text { penjelasan } \\
\text { pointnya } \\
\text { tidak } \\
\text { sesuai }\end{array}$ \\
\hline $\begin{array}{l}\text { Band } \\
6 \\
0-2\end{array}$ & $\begin{array}{l}\text { Penjelasan isi } \\
\text { tidak jelas atau } \\
\text { membingung } \\
\text { kan }\end{array}$ & $\begin{array}{l}\text { Ada satu atau } \\
\text { dua butir } \\
\text { penjelasan } \\
\text { tentang bahasa } \\
\text { teks, namun } \\
\text { tidak jelas }\end{array}$ & $\begin{array}{l}\text { Makna } \\
\text { kalimat } \\
\text { terputus, } \\
\text { pendek, } \\
\text { tidak } \\
\text { terstruktur }\end{array}$ \\
\hline
\end{tabular}

Terjemahan Mark Scheme A/AS Level

Mark Scheme GCE A/AS LevelOctober/Novemver 2009 Syllabus 8693 paper 12 Part (b)- Directed Writing (Tabel 4)

Mark

\begin{tabular}{|l|l|}
\hline $8-10$ & $\begin{array}{l}\text { Persepsi mengenai teks, pembaca dan tujuan } \\
\text { kuat, pemakaian kosakata tepat ekspresi bahasa } \\
\text { sesuai dengan yang ditanyakan dan diharapkan } \\
\text { Respon yang diharapkan pada level/ band ini } \\
\text { adalah persuasive dan pasti. Ditopang dengan } \\
\text { pemahaman individu yang konsisten terhadap } \\
\text { pembacanya, isi dan tujuan, menggunakan } \\
\text { ekspresi bahasa yang mengalir dan lugas. }\end{array}$ \\
\hline $6-7$ & $\begin{array}{l}\text { Mencerminkan informasi tujuan, konteks dan } \\
\text { relevansi yang jelas, di topang dengan usaha } \\
\text { pemaparan bahasa yang lugas, sesuai dengan } \\
\text { permintaan dan harapan dalam tugas }\end{array}$ \\
\hline $4-5$ & $\begin{array}{l}\text { Ada usaha yang cukup tetapi diikuti dengan } \\
\text { dengan ke- tidak-seimbangan dan kepastian } \\
\text { tujuan, isi dan gaya bahasa. Secara umum terlihat } \\
\text { ada ekspresi dan ketepatan bahasa }\end{array}$ \\
\hline $2-3$ & $\begin{array}{l}\text { Ada jawaban, tetapi terbatas karena ada } \\
\text { ketidaktepatan gaya, tujuan dan bahasa secara } \\
\text { menyeluruh. Ekspresi dan ketepatan bahasa } \\
\text { sangant terbatas }\end{array}$ \\
\hline $0-1$ & $\begin{array}{l}\text { Membingungkan dan tidak ada focus dalam } \\
\text { tujuan, isi, pembaca. Secara keseluruhan } \\
\text { pemakaian bahasa dan gaya tidak tepat. } \\
\text { Penulisan singkat terputus dan ekspresi yang } \\
\text { terbatas }\end{array}$ \\
\hline
\end{tabular}

Terjemahan mark scheme part $B$ directed writing

Contoh soal yang merujuk pada kriteria penilaian diatas adalah sebagai berikut:

\section{Paper 1. Passage for Comment October/November 2009. 8693/12 (2hours)}

1. The following passage describes the writer's experience in North America when he tries to locate the mysterious creature known as Bigfoot. His guide-who whishes to be known only as M.F.shows him the area in which the creatures supposedly live.

a) Comment on the style and language of the passage (15 Marks)

b) Inspite of his promise to the guide (M.F.) not to reveal the sacred place, the writer sends an exicited letter to a colleague relating his experiences. Basing your answer closely on the material of the original extract, write the opening section (between 120- 150 words) of the letter (10 marks).

\subsubsection{Mark Scheme- GCE A/AS Level-} October/November 2009. Syllabus 8693 paper 21. Section A: Narrative/Descriptive/Imaginative Writing (Tabel 5)

\begin{tabular}{|c|c|c|}
\hline $\begin{array}{l}\text { Band } \\
1\end{array}$ & $\begin{array}{l}22- \\
25\end{array}$ & $\begin{array}{l}\text { - Imaginatif, kemungkinan orisinil, } \\
\text { pendekatan yang sesuai, menarik } \\
\text { perhatian pembaca; } \\
\text { - Sangat terkontrol, struktur yang } \\
\text { lugas/tepat; } \\
\text { - Bahasa yangdigunakan menciptakan } \\
\text { nuansa emotif dan imaginatif; } \\
\text { - Mahir, ekspresi bahasa yang matang, } \\
\text { mencapai efek kompleks, dengan tingkat } \\
\text { ketepatan yang lugas; }\end{array}$ \\
\hline $\begin{array}{l}\text { Band } \\
2\end{array}$ & $\begin{array}{l}18- \\
21\end{array}$ & $\begin{array}{l}\text { - Pendekatan pada soal cukup imaginatif, } \\
\text { sesuai untuk pembaca dan menarik; } \\
\text { - Efektif, struktur yang tepat; } \\
\text { - Bahasa yang digunakan menciptakan } \\
\text { nuansa emotif dan imaginatif pada } \\
\text { pembaca, }\end{array}$ \\
\hline $\begin{array}{l}\text { Band } \\
3\end{array}$ & $\begin{array}{l}14- \\
17\end{array}$ & $\begin{array}{l}\text { - Terfokus dan konsisten pada bentuk dan } \\
\text { isi yang sesuai, dengan merujuk pada } \\
\text { pembaca yang tepat } \\
\text { - Struktur jelas dan cocok dengan apa yang } \\
\text { dituntut dalam tugas } \\
\text { - Usaha menciptakan efek bahasa terasa } \\
\text { dan tercapai, dan sesuai baik dalam } \\
\text { narratif maupun diskriptif. }\end{array}$ \\
\hline $\begin{array}{l}\text { Band } \\
4\end{array}$ & $\begin{array}{l}10- \\
13\end{array}$ & $\begin{array}{l}\text { - Fokus jelas, sesuai dengan bentuk dan } \\
\text { isi,dengan beberapa sentuhan imaginasi, } \\
\text { dan merujuk pada pembaca/audience } \\
\text { yang sesuai; } \\
\text { - Strukturnya sudah benar walau tidak } \\
\text { sepenuhnya konsisten- dan fokusnya naik } \\
\text { turun tidak konsisten ; } \\
\text { - Usaha terhadap effek bahasa tepat, baik } \\
\text { ketepatan dalam narasi maupun deskripsi; } \\
\text { - Ekspresi bahasa jelas, variasi tidak } \\
\text { banyak dan terlihat ada kesalahan teknis } \\
\text { penulisan (tenses yang membingungkan, } \\
\text { subject/verb agreement yang salah, ada } \\
\text { penulisan yang salah dan tanda baca) }\end{array}$ \\
\hline
\end{tabular}




\begin{tabular}{|c|c|c|}
\hline & & $\begin{array}{l}\text { yang semua ini membatasi pencapaian } \\
\text { nuansa effek. }\end{array}$ \\
\hline $\begin{array}{l}\text { Band } \\
5\end{array}$ & $6-9$ & $\begin{array}{l}\text { - Ada bentuk dan isi yang sesuai dengan } \\
\text { beberapa keselarasan audience/pembaca; } \\
\text { - Struktur tidak sepenuhnya jelas- bisa } \\
\text { terpapar tanpa ada control narasi atau } \\
\text { perbedaaan dengan deskripsi } \\
\text { - Ada usaha terhadap effek bahasa, yang } \\
\text { sesuai secara baik deskriptif maupun } \\
\text { naratif } \\
\text { - Ekspresi bahasa jelas tetapi tidak lancar, } \\
\text { dengan terjadinya beberapa kesalahan } \\
\text { teknis penulisan (tenses yang } \\
\text { membingungkan,subject/verb agreement } \\
\text { yang salah, ada penulisan yang salah dan } \\
\text { tidak hadirnya tanda baca) }\end{array}$ \\
\hline $\begin{array}{l}\text { Band } \\
6\end{array}$ & $2-5$ & $\begin{array}{l}\text { - Ada bukti usaha untuk memfokuskan diri } \\
\text { pada ide yang tepat untuk isi, atau yang } \\
\text { cukup diterima namun tidak sepenuhnya } \\
\text { pertanyaan tepat terjawab } \\
\text { - Bentuk bahasa nya kurang meyakinkan, } \\
\text { misalnya untuk menjawab pertanyaan } \\
\text { deskriptif dijelaskan seutuhnya dalam } \\
\text { narasi } \\
\text { - Strukturnya tidak ada,/lemah, dan tidak } \\
\text { terarah } \\
\text { - Kadang-kadang tercipta effek bahasa, } \\
\text { baik dalam narasi maupun deskripsi } \\
\text { - Ekspresi bahasa kadang tidak jelas; } \\
\text { terdapat kesalahan teknis dan masalah } \\
\text { struktur bahasa (tenses } \\
\text { membingungkan,subject/verb agreement } \\
\text { yang salah, sering ada/ejaan/penulisan } \\
\text { yang salah dan tidak hadirnya tanda baca) } \\
\text { sangat mengganggu alur keseluruhan } \\
\text { penulisan. }\end{array}$ \\
\hline $\begin{array}{l}\text { Band } \\
7\end{array}$ & $0-1$ & $\begin{array}{l}\text { - Hasil penulisan tidak menjawab tugas } \\
\text { pertanyaan, bingung atau /tidak logis dan } \\
\text { pengetahuan yang kurang akan bentuk } \\
\text { dan isi yang sesuai. } \\
\text { - Adanya kelemahan dalam } \\
\text { pengorganisasian penulisan dan ketidak- } \\
\text { tepatan teknik penulisan (Pengertian yang } \\
\text { membingungkan mengenai, subject /verb } \\
\text { agreement yang salah, ada penulisan yang } \\
\text { salah dan tidak hadirnya tanda baca) } \\
\text { sehingga peserta ini mendapat hambatan } \\
\text { serious dalam menciptakan impresi secara } \\
\text { menyeluruh }\end{array}$ \\
\hline
\end{tabular}

Terjemahan mark scheme paper 21

\section{Section B: Discursive/Argumentative Writing} (Tabel 6)

\begin{tabular}{|c|c|c|}
\hline $\begin{array}{l}\text { Band } \\
1\end{array}$ & $\begin{array}{l}22- \\
25\end{array}$ & $\begin{array}{l}\text { - Menarik;pendekatan pada task/tugas } \\
\text { sangat kuat/hidup; kemungkinan orisinil, } \\
\text { bentuk yang sesuai, menarik perhatian } \\
\text { pembaca; } \\
\text { - Sangat terkontrol, struktur mengembang } \\
\text { kan gagasan utama dengan gaya yang } \\
\text { logis dan efektif } \\
\text { - Penggunaan bahasa yang beragam dan } \\
\text { ada perangkat retorikal yang digunakan } \\
\text { secara efektif untuk menjelaskan, } \\
\text { berargumentasi atau membujuk; } \\
\text { - Mahir, ekspresi bahasa yang matang, }\end{array}$ \\
\hline
\end{tabular}

\begin{tabular}{|c|c|c|}
\hline & & $\begin{array}{l}\text { mencapai efek argumentasi yang } \\
\text { kompleks, dengan } \\
\text { teknis yang tinggi }\end{array}$ \\
\hline $\begin{array}{l}\text { Band } \\
2\end{array}$ & $\begin{array}{l}18- \\
21\end{array}$ & $\begin{array}{l}\text { - Pendekatan pada task/tugas cukup } \\
\text { tajam, bentuk yang tepat dan pembaca } \\
\text { menjadi tertarik; } \\
\text { - Efektif, struktur yang tepat dengan } \\
\text { penjabaran gagasan/argumentasi yang } \\
\text { jelas; } \\
\text { - Bahasa dan perangkat retorikal yang } \\
\text { digunakan dalam menjelaskan, } \\
\text { berargumentasi atau membujuk sangat } \\
\text { effektif; } \\
\text { - Ekspresi lancar mampu menciptakan } \\
\text { argument yang kompleks, kadang terjadi } \\
\text { kesalahan teknis tapi tidak merusak } \\
\text { ekspresi. }\end{array}$ \\
\hline $\begin{array}{l}\text { Band } \\
3\end{array}$ & $\begin{array}{l}14- \\
17\end{array}$ & $\begin{array}{l}\text { - Terfokus dengan konsisten pada bentuk } \\
\text { dan isi yang sesuai, dengan merujuk } \\
\text { pada pembaca yang tepat } \\
\text { - Struktur yang jelas yang memperlihat } \\
\text { kan pengembangan; } \\
\text { - Terdapat perangkat bahasa dan retorikal } \\
\text { digunakan untuk menjelaskan, } \\
\text { berargumentasi dan membujuk; } \\
\text { - Ekspresi penulisan yang jelas dengan } \\
\text { beberapa variasi, walau ada } \\
\text { ketidaktepatan dalam teknik penulisan }\end{array}$ \\
\hline $\begin{array}{l}\text { Band } \\
4\end{array}$ & $\begin{array}{l}10- \\
13\end{array}$ & $\begin{array}{l}\text { - Fokus yang jelas, sesuai dengan bentuk } \\
\text { dan isi, dengan merujuk pada pembaca/ } \\
\text { audience yang sesuai; } \\
\text { - Strukturnya sudah benar walau tidak } \\
\text { sepenuhnya konsisten- dan fokusnya } \\
\text { naik turun tidak konsisten atau kadang } \\
\text { kala keluar jalur; } \\
\text { - Usaha terhadap effek bahasa tepat, baik } \\
\text { ketepatan dalam menjelaskan, } \\
\text { berargumentasi atau membujuk untuk } \\
\text { beberapa tujuan, tidak sepenuhnya } \\
\text { berhasil; } \\
\text { - Ekspresi bahasa jelas, variasi tidak } \\
\text { banyak dan terlihat ada kesalahan teknis } \\
\text { penulisan (tenses yang membingungkan, } \\
\text { subject/verb agreement yang salah, ada } \\
\text { penulisan yang salah dan tanda baca) } \\
\text { yang semua ini membatasi pencapaian } \\
\text { nuansa effek. }\end{array}$ \\
\hline $\begin{array}{l}\text { Band } \\
5\end{array}$ & $6-9$ & $\begin{array}{l}\text { - Ada bentuk dan isi yang sesuai dengan } \\
\text { beberapa keselarasan audience/pembaca; } \\
\text { - Struktur tidak sepenuhnya jelas- bias } \\
\text { tidak mampu memaparkan } \\
\text { pengembangan atau argumentasi; } \\
\text { - Ada usaha untuk menciptakan effek } \\
\text { bahasa, yang sesuai saat menjelaskan, } \\
\text { berargumentasi atau membujuk; } \\
\text { - Ekspresi bahasa jelas tetapi tidak lancar, } \\
\text { dengan terjadinya beberapa kesalahan } \\
\text { teknis penulisan (tenses yang } \\
\text { membingungkan, subject/verb } \\
\text { agreement yang salah, ada penulisan } \\
\text { yang salah dan tidak hadirnya tanda } \\
\text { baca) }\end{array}$ \\
\hline $\begin{array}{l}\text { Band } \\
6\end{array}$ & $2-5$ & $\begin{array}{l}\text { - Mencoba membuat hasil tulisan sesuai } \\
\text { dengan task/tugas, atau dapat } \\
\text { dimengerti, tapi tidak seutuhnya men } \\
\text { jawab pertanyaan, dan cenderung ada }\end{array}$ \\
\hline
\end{tabular}




\begin{tabular}{|c|c|c|}
\hline & & $\begin{array}{l}\text { topic yang harus diperhitungkan/ } \\
\text { dipertanyakan; } \\
\text { - Strukturnya tidak ada,/lemah, dapat } \\
\text { melompat dari satu gagasan ke gagasan } \\
\text { yangtidak berkaitan, keluar jalur dan } \\
\text { berpanjang lebar; } \\
\text { - Kadang-kadang tercipta effek bahasa, } \\
\text { baik dalam menjelaskan, berargumentasi } \\
\text { atau membujuk; } \\
\text { - Ekspresi bahasa kadang tidak jelas; } \\
\text { terdapat kesalahan teknis dan masalah } \\
\text { struktur bahasa (tenses yang mem } \\
\text { bingungkan, subject/verb agreement } \\
\text { yang salah, sering ada /ejaan/penulisan } \\
\text { yang salah dan tidak hadirnya tanda } \\
\text { baca) sangat mengganggu alur keseluruh } \\
\text { an penulisan. }\end{array}$ \\
\hline $\begin{array}{l}\text { Band } \\
7\end{array}$ & $0-1$ & $\begin{array}{l}\text { - Hasil penulisan tidak menjawab tugas } \\
\text { pertanyaan, bingung atau /tidak logis } \\
\text { dan memiliki sedikit pengetahuan topik } \\
\text { yang dipilih;. } \\
\text { - Adanya kelemahan dalam } \\
\text { pengorganisasian penulisan dan ketidak- } \\
\text { tepatan teknik penulisan (Pengertian } \\
\text { yang membingungkan mengenai, subject } \\
\text { /verb agreement yang salah, ada } \\
\text { penulisan yang salah dan tidak hadirnya } \\
\text { tanda baca) sehingga peserta ini } \\
\text { mendapat hambatan serious dalam men } \\
\text { ciptakan impresi secara menyeluruh }\end{array}$ \\
\hline
\end{tabular}

Terjemahan Mark Scheme paper 21

Contoh soal yang merujuk pada kriteria penilaian diatas adalah sebagai berikut:

Paper 2. Composition, October/November 2009. 8693/21

Answer one question from Section $A$ and one question from Section $B$

Write between 600 and 900 words for each composition. (2 hours)

\section{Section A: Narrative/Descriptive/Imaginative writing.}

1. Write an opening chapter of a novel entitled The Soldier's story. In it you should create a sense of mood and character.

\section{Section B: Discursive/ argumentative Writing}

2. 'These days there is too much state control' "we need as much protection by the state as possible' What do you think and why?

\subsubsection{Analisis Hasil Ujian A/AS Level Siswa SMA 70}

Siswa yang mengikuti ujian berjumlah 20 orang. Hasil tes mereka akan dinilai berdasarkan gabungan paper 1 dan paper 2. Tes ini dikerjakan disekolah sesuai jam ujian yang diterapkan yakni dua jam. Sebenarnya masing masing paper dilaksanakan dalam dua jam. Tetapi karena siswa SMA 70 memiliki kegiatan yang sangat padat menjelang akhir tahun pembelajaran, maka dalam dua jam itu mereka harus melaksanakan kedua paper dengan cara memilih salah satu soal dari masing masing paper 1 dan paper 2 . Hal ini dibutuhkan karena paper 1 dan paper 2 memiliki jenis pertanyaan yang berbeda tetapi sangat penting untuk diketahui tingkat kemampuan siswa terhadap kedua jenis materi tes yang berbeda tersebut.

Setelah di analisis, keseluruhan hasil tes paper 1 dan paper 2 dikelompokan menjadi tiga bagian. Bagian pertama adalah karya siswa yang termasuk paling rendah baik dinilai dari bahasa yang digunakan, ketepatan menjawab maupun jumlah kata yang diwajibkan oleh tes A/AS Level. Kendala utama adalah ketidak mampuan siswa menulis sehingga, dari hasil penulisan yang sangat pendek tidak mungkin dapat memenuhi kriteria penilaian. Disamping itu, ada siswa yang tidak mampu mengartikan pertanyaan yang diberikan, sehingga jawabannya menjadi menyimpang dan tidak jelas. Contoh jawaban dari paper 1 dalam menganalisis atau memberi komentar tentang tulisan si penulis text.

The language is a little compicated. Use a lot of complicated word.grammatically perfect.not to the point ( Heidy). Contoh lain, The language is hard to understand, the words are too complicated, hard to find the major point of the story. Disini yang tercermin bukan bagaimana teks itu seharusnya di analisis, melainkan bagaimana sulitnya bagi siswa tersebut memahami teks yang dibacanya. Ada kesalahan mengeja dan kalimat (Audrey).

Kelompok ke dua, adalah siswa yang telah memiliki pemahaman mencerna dengan lebih baik walaupun banyak kesalahan dan keterbatasan. Contoh jawaban mereka antara lain: I think the speaker has formal style of language. She is telling to much information, maybe it is better she makes it more simple (Riola). Contoh lain, First person speaker, he uses the proper grammar, comedy style, the writer asks the reader some questions, therefore its interactive. There are lots of information, therefore what he said are proven and believable (Rizki).

Kelompok ke tiga adalah yang terbaik. Mereka mampu melihat dan menjabarkan dengan rinci atas pemahaman mereka terhadap text. Contohnya: I think that when I read the passage, the speaker used the formal language and exaggerate words. The speaker used contraction which is not common for formal speech, I also think the speaker used the right diction for the speech.There was no problem in the grammar that the speaker used in the speech (Permana).Contoh lain, His style of writing is a kind of poetic. There are signs that he is very 
curious about the Bigfoot. He is easily impressed and very knowledgeable about occult stuffs. (Elmo). Contoh lainnya:I reckoned that when I saw, the passage, most of the words that are used is informal-language- based. It can be found in the word 'edgy' and lots of contraction words. I believe that this speaker is exaggerating his point of view, most of the words are uncertain from reality and using sarcasmic words to whom that he does not like ( Ramsey). Untuk menerapkan penempatan Band pada tulisan siswa, untuk yang pertama adalah Band 6, merupakan nilai terkecil dengan marks antara $0-2$. Sebagian besar ada pada Band 5 yakni marks 3-5 dan yang tertinggi Band 4 dengan marks 6-7.

Hasil tulisan paper 2 composition tidak berbeda. Pengelompokan juga tercermin pada tiga kelompok. Kelompok pertama adalah kelompok yang terlemah. Mereka termasuk criteria Band 6 kedua dari yang terkecil dengan marks 3-5. Contoh karya mereka adalah: In 2025, every people will joins together and unite. No more country or nations. Everything will be one. No more different. Oxygen and virus epidemic grow from $25 \%$ to $80 \%$ people use their guns such as nuclear bomb to destroy each other (as known as world war 3). America needs more fuel and resources (Radifan).

Kelompok kedua berekspresi lebh banyak dan lebih hidup walau mereka masih jauh dari harapan untuk menulis antara 600 sampai dengan 900 kata dengan baik. Contohnya: It's been 12 months since I got here, Every night I keep thinking about home, but my heart wants to be here. "Man, wake up! The Colonel wants to talk to you 'Tony said, "ugh, what do he wants?' I replied. It's three o'clock in the morning, I just got into my tent ( Carrisa). Kelompok kedua dapat dikategorikan ke dalam Band 5 dengan marks 5-7. Disini siswa mampu menjabarkan dengan hidup, namun percakapannya pendek dan tidak formal dengan pilihan kata yang umum

Kelompok ketiga mencerminkan penulisan yang lebih mengalir dan enak dibaca. Contohnya paper 2 b: I think state control will be very helpful when it is important to our life and our activities, and state control will be very unimportant when it bans you from kissing your wife on Sunday! Well, that is the fact from one of the state in USA. The state control is intended to maintain the public order in itself. Most of them were published because of regular or constant complains in specific public sectors, the state government discuss it with some researchers and trial-and-error methods which suit the best for tackling the chaos. As it is, it will have negative impact as soon as the law has been published. It is published because the majority of election in the state, the minority, such as the leftist, the skinhead community as it is same with the pro-nazi community in Germany. But I believe, the state control is the best way to control citizen with their very own best situation and condition in their life, for example youth curfew decreases $70 \%$ of criminal numbers commited by youth generation, which is a tremendous preventive action that we could do(Ramsey). Apabila dilihat dari persyaratan jumlah kata yang harus dicapai yakni 600 sampai dengan 900 memang tidak mencukupi. Kesalahan grammatika juga masih ada seperti 'it is same' harusnya ' it is the same'. Namun tulisan ini sudah memiliki karakter, alur yang logis dan pengetahuan yang memadai mengenai topic bahasan. Pemilihan kata juga sudah sangat beragam. Contoh lainnya juga mencerminkan character yang kuat namun berbeda. Contoh paper 2 Section A. There was rustling, a faint groaning in the distance, an icy air all around, the cold icy air tingling to the spine. I got goose bumps from hearing it's breath, the sound of footsteps get louder everytime, it's piercing eye stared at me with murderous intents. I keep running and running and running, stil it kept following me, my breath is getting harder as I go on, my lungs were bursting out of oxygen, my sweat were flowing like flood, the sterich of vapourish sweat and blood, the wounds were opening again. I checked my wounds and it was bleeding and infected, the wet grassy, slippery area was making me slip all the time, the sky look restless, rumbling of thundering was barging like the drums,trees, large trees obstacling my path, it was scary just to look back, knowing that many of my commarades were taken. I remembered when it ripped the neck of one of my comrades, blood gushing out like it will not stop, the screams that led me to tears and fears, my body was tingling everyime, my hand were blue, cold, and wet, my nails were not there, the pain stung and my nails were not white anymore, it was red from blood and infection, my sights were blurry. I could not hardly see the way, and without warning.....( Elmo). Tulisan Elmo tidak sebaik tulisan Ramsey karena terdapat banyak kelemahan. Kesalahan grammatika sangat jelas terlihat seperti 'my sweat were flowing' seharusnya 'is flowing'. Alur cerita tidak kuat bahkan cenderung tidak terarah. Jumlah kata juga tidak mencapai persyaratan yang diminta yakni diatas 600 kata. Namun, Elmo mampu menciptakan dan mengembangkan ungkapan emosi yang tinggi, rasa panik dan ketakutan dalam tulisannya karena is memakai banyak adjectives dan ini yang diharapkan terjadi. Gaya penulisan sudah 
berkarakter. Kemungkian besar, Elmo sering membaca novel sehingga ia merasa nyaman menuangkan gaya bahasa yang sama. Keduanya mampu menciptakan effek bahasa dan mendapat band 3/4 atau sama dengan nilai nilai (mark) 14-27/ $10-13$.

Dari analisis hasil tes A/AS Level English Language siswa SMA 70 Jakarta, dapat dikatakan bahwa sebagian besar belum mampu mengerjakan ujian di tingkat ini dan hanya ada dua contoh yang cukup baik namun belum siap sepenuhnya karena mereka tidak menulis sesuai permintaan jumlah kosa kata yang seharusnya mencapai antara $600-$ 900 kata, walau dalam mengungkapkan effek bahasa mereka sudah sampai pada tingkat awal A/AS level. Kondisi yang terjadi merupakan suatu proses kemajuan pembelajaran yang telah dicapai selama mereka berada dalam bimbingan kelas internasional di SMA 70 Jakarta.

\subsection{Analisis Kuesioner dan Wawancara Tertulis}

Analisis hasil ujian IGCSE siswa SMA 70 dan tes A/AS Level sudah memberikan bukti yang jelas mengenai kesulitan yang dihadapi siswa ketika mengerjakan A/AS level. Untuk memperkuat temuan diatas, Kuestioner diberikan kepada siswa yang sama dua minggu sesudah mereka mengerjakan tes A/AS Level. Hasil kuesioner memperlihatkan bahwa: 11 siswa dari 20 menjawab 'mampu menyelesaikan 7 exercises IGCSE dengan baik'. Jumlah yang sama juga setuju 'text Exercise 1 IGCSE mudah dipahami'. Sementara hanya 1 siswa yang sangat tidak setuju di kedua pernyataan diatas. 13 siswa setuju 'exercise 2 IGCSE memiliki text yang panjang namun masih masih dapat ditangkap makna dan pertanyaannya". Untuk exercise 3 yang 'melatih memindahkan makna suatu wacana kedalam format lain' dijawab 9 murid dengan ragu ragu atas rasa suka melaksanakan bagian ini. 12 Siswa setuju bahwa 'exercise 4 dan 3 memiliki persaman yakni 'mencari inti informasi yang diminta' dan hanya 1 yang sangat tidak setuju. 'Membuat ringkasan dalam 70 kata sangatlah mudah' disangkal oleh siswa karena 9 siswa mengatakan ragu ragu atas pernyataan ini. Satu jawaban yang diluar dugaan adalah 13 siswa ragu atas pernyataan bahwa "menjawab 2 soal di A/AS Level tidak mencukupi'". Disini ada kecenderungan bahwa mereka mampu menyelesaikan dalam 2 jam namun mereka tidak mengantisipasi atas kesempurnaan tulisan mereka untuk lulus di level ini. Keraguan mereka ternyata terbantah dengan pernyataan 'waktu 2 jam yang diberikan dalam mengerjakan A Level sangatlah kurang karena mereka harus mengedit tulisan mereka'di setujui oleh 9 siswa. Jawaban yang baik ada pada pertanyaan no 16. 13 siswa setuju melakukan 'review' dari suatu wacana memerlukan 'analitical dan critical thinking' pada paper 1 pertanyaan no 3 A/AS Level. Terakhir, 10 siswa sangat setuju bahwa 'tingkat A/AS Level jauh lebih sulit dari IGCSE'. Demikian hasil kuesioner. Secara keseluruhan hasil questioner mencerminkan kesesuaian dengan hasil tes A/AS Level dimana mereka mengalami lompatan kesulitan yang cukup besar dari IGCSE ke A/AS Level.

\subsection{Analisis Wawancara}

Kegiatan wawancara tertulis ditujukan pada seorang guru SBI dan cuplikannya sebagai berikut:

P: Bagaimana kiat ibu mempersiapkan siswa menghadapi ujian Engish Language A/AS Level, jika sekolah menyediakan waktu yang cukup untuk itu.

J: Saya kira, waktu yang cukup untuk mempersiapkan itu adalah 2 x135 menit per minggu selama 2 tahun. Mereka haru terbiasa membaca berbagai bentuk teks dan buku. Kemudian mengungkapkan analisa dan opini tentang teks dan buku tersebut secara efektif. Di samping itu, latihan membuat komposisi secara efektif dengan tata bahasa yang baik juga harus terus dilakukan. Proses belajar itu dapat dilakukan dalam bentuk tugas, seperti, membuat jurnal, artikel, resensi buku, buku harian dan lainnya.

Wawancara tertulis ini mencerminkan kesulitan mencapai standar kriteria A/AS Level dengan waktu yang hanya tersedia 1x135 menit seminggu. Disamping itu, ada kendala kelemahan dalam membiasakan menulis dalam kegiatan sekolah sehingga siswa mendapat kesulitan memenuhi persyaratan A/as Level dengan baik. Kelemahan lain ada di penguasaan kosakata yang terbatas dan keharusan guru menerapkan gabungan antara kurikulum nasional dan internasional dalam jumlah jam yang terbatas.

\subsection{Assesment Materi IGCSE, A/AS Level}

Apabila perbedaan tingkat kesulitan materi IGCSE dan A/AS Level sudah diketahui dari berbagai analisis data di atas, maka hal yang sangat penting adalah melihat secara rinci dan mendalam perbedaan tersebut melalui pengamatan perbandingan materi kedua tingkatan yakni IGCSE dengan A/AS Level. 


\subsubsection{Rincian Cambridge IGCSE English as a Second Language Syllabus code 0510}

Seperti telah dijelaskan sebelumnya, setiap peserta ujian IGCSE dapat memilih antara Core atau Extended IGCSE. Yang telah dilaksanakan Siwa SMA 70 adalah Extended IGCSE. Rincian Silabus dan assesmen yang diterbitkan oleh University of Cambridge International Examinations adalah sebagai berikut:

\section{A The aims are to:}

1. develop the ability to use English effectively for the purpose of practical communication;

2. form a sound base for the skills required for further study or employment using English as the medium;

3. develop an awareness of the nature of language and language-learning skills, along with skills of a more general application;

4. promote students'personal development.

B Assessment objectives: Candidate must demonstrate ability in the following areas:

\section{Reading}

$R 1$ understand and respond to information presented in a variety of forms

$R 2$ select andorganise material relevant to specific purposes

$R 3$ recognise, understand and distinguish between facts, ideas and opinions

$R 4$ infer information from text (Extended tier only)

\section{Writing}

W1 communicate clearly, accurately and appropriately

W2 convey information and express opinions effectively

W3 employ and control a variety of grammatical structures

W4 demonstrate knowledge and understanding of a range of appropriate vocabulary

W5 observe conventions of paragraphing, punctuation and spelling

W6 employ appropriate register/style

\section{Listening}

$\mathrm{Li}$ understand and respond to information presented in a variety of forms

$T 2$ recognise, understand and distinguish between facts and opinions

T3 select and organize material relevant to specific purposes

L4 infer information from texts (Extended tier only)

\section{Speaking}

Slcommunicate clearly, accurately and appropriately

S2 convey information and express opinions effectively

S3employ and control a variety of grammatical structures

S4demonstrate knowledge of a range of appropriate vocabulary

S5 engage in and influence the direction of conversation

S6 employ suitable pronounciation and stree patterns

\section{Curriculum content- Paper 2- reading and writing (extendend)}

Ada 7 tugas yang harus dikerjakan.

Overview of exercises on Paper 2 (Tabel 7)

\begin{tabular}{|l|l|}
\hline Exercise 1 & $\begin{array}{l}\text { Reading1 reading short text and answer a } \\
\text { series ofquestions testing skim-/gist reading } \\
\text { skills. Candidates write short (single } \\
\text { word/phrase) answers.Text type: } \\
\text { advertisement, brochure, leaflet, guide, } \\
\text { report, manual, instructions. }\end{array}$ \\
\hline Exercise 2 & $\begin{array}{l}\text { R2 R4 Candidate read a text and answer a } \\
\text { series of questions testing more on detailed } \\
\text { comprehension. A report or a articlewhich } \\
\text { newspaper/magazine } \\
\text { incoorperate a graphical element }\end{array}$ \\
\hline Exercise 3 & $\begin{array}{l}\text { Information transfer Rl,R2,R4, W1.W2. } \\
\text { Candidates complete a form or notes using } \\
\text { information provided on the question paper }\end{array}$ \\
\hline Exercise 4 & $\begin{array}{l}\text { R1,R2,R3 Note making } 2, \text { R3,W1,W2,W3,W4,W5 Summary } \\
\text { writing of a 100-200 words }\end{array}$ \\
\hline Exercise 5 & $\begin{array}{l}\text { W1,W2,W3,W4,W5 Candidate write } \\
\text { between 150-200 words of continuous } \\
\text { prose }\end{array}$ \\
\hline Exercise 6 & $\begin{array}{l}\text { W1,W2,W3,W4,W5,W6 Candidate write } \\
\text { between 150-200 words of continuous } \\
\text { prose }\end{array}$ \\
\hline Exercise 7
\end{tabular}

Kemahiran di IGCSE Level secara merata didistribusikan pada Reading, Writing, Listening dan Speaking. Dalam Reading, siswa harus menguasai reading skills, note-making, membaca dan mengerti bahkan memindahkan informasi dari text dalam bentuk graph, table, iklan, informasi public, majalah, laporan dan jurnal. Dalam Writing, siswa harus mampu membuat ringkasan, mengisi formulir, menulis surat dan beragam jenis register penulisan. Ulasan opini atau penulisan prosa dituangkan dalam paragraph dengan jumlah kata $100-150$ kata mengenai beragam situasi. Kemahiran mendengar/Listening mencakup kemampuan menangkap percakapan pendek, dialog, interview dan mendengar percakapan yang lebih panjang. Speaking diberikan dalam waktu 10 menit. Dalam Speaking ada 2 tahapan yang harus 
dikerjakan oleh peserta ujian lisan. Pertama, peserta mendapat 3 menit untuk menceritakan tentang dirinya. Kemudian, peserta diberi waktu antara 6-9 menit untuk berbicara dan berperan sesuai dengan kartu topik yang didapatnya. Dalam menilai kemahiran berbicara faktor kebahasaan yang dinilai adalah Struktur bahasa, kosakata, dan pengembangan topik beserta kelancaran bicara.

\subsubsection{English Language A/AS Level}

Dalam kelompok A/AS Level, English Language dari syllabus 8693 merupakan level yang mendasar yang diterbitkan oleh University of Cambridge International Examinations.

\section{A. Aims}

To encourage:

- a critical and informed response to write in a range of forms, styles and contexts

- $\quad$ The interdependent skills of reading, analysis and communication

- Effective and appropriate communication

\section{B. Assessment Objectives}

Candidates for English Language will be required to demonstrate:

$i$. Ability to read with understanding written material in a variety of forms, and to comment on its effectiveness.

ii. Knowledge and understanding of features of English Language

iii. Ability to write clearly, accurately and effectively for particular purpose or audience.

\section{Description of papers- English Language}

Paper 1-passages for Comment (2 hours)

Each question will be based on a passage,or passages. On text printed in the question paper. These will be taken from a balanced range of sources, and will include informative and narrative writing in a wide variety of styles.

Candidates should be able to identify distinguishing features of passages, and to relate them to the function and context of writing, and to organize information in their answers. They should be able to comment on aspects such as vocabulary, figurative language (e.g. use of metaphore and simile), word- ordering and sentence structure, formality/informality of tone, and the communication of attitudes, bias or prejudice. In the directed writing task they should demonstrate the ability to write for specific purpose and/or audience using appropriate vocabulary, tone and style.

Dalam Paper 1. Siswa harus mampu mengidentifikasi karakter teks dan mengulasnya dari segi fungsi dan gaya penulisan, kemudian mengolah informasi yang harus dituangkan dalam tulisan. Mereka harus mampu mengupas pengaruh pemakaian kosakata yang berfungsi sebagai metafor, simile dan bentuk lain dari makna yang tersirat atau figurative language yang menjadi karakter wacana kesusastraan. Siswa harus memperhatikan jenjang tingkat kata, struktur kalimat, formalitas nada bahasa, sikap penulis dalam menyampaikan maksudnya. Di bagian directed writing task siswa harus menulis karangan untuk tujuan dan pembaca tertentu dengan menggunakan kata-kata, gaya bahasa dan nada yang sesuai dengan situasinya.

\section{Paper 2- Composition (2hours)}

The paper will be divided into two sections: Section A: Narrative/Descriptive/Imaginative Writing and Section B: Discursivel Argumentative Writing. There will be a choice of four composition tasks in each section. Candidates will attempt two tasks, one taken from each section. Questions carry equal marks. Candidate should write between 600-900 words for each composition.

In both section, candidates are required to demonstrate accurate use of language in an appropriatestyle, clearly presented. In addition, in section a candidates should demonstrate the ability to write an imaginative piece, using language to create deliberate effects, such as creating a mood or creating a character, in section $B$ candidates should demonstrate the ability to construct an argument, presenting a view or views clearly, coherently, and persuasive

Paper 2 merupakan bagian yang paling sulit dimana pada pertanyaan A dan B siswa harus menulis 600 -900 kata. Dari 4 soal di bagian A, siswa diminta untuk mengulas suatu wacana dari sisi positif dan negative menurut siswa dalam jenis penulisan narasi/diskripsi/ imaginasi. Dibagian B, siswa harus menulis dengan menggunakan bahasa yang tepat, pemakaian gaya bahasa yang tepat dengan penyajian yang jelas.

Di samping itu, siswa harus mampu menulis karangan bernuansa imaginasi, memakai bahasa yang dapat menciptakan emosi atau perasaan tertentu, seperti menciptakan rasa takut yang besar atau menciptakan karakter tokoh secara rinci. Siswa dituntut untuk mampu merancang karangan 
argumentasi, menjabarkan opininya secara lugas, jelas dan meyakinkan. Penulisan dalam paper 2 memberi kebebasan siswa untuk berkreasi secara menyeluruh.

\section{KESIMPULAN}

Materi IGCSE menekankan pada semua skills. Writing, Reading, Speaking dan Listening yang mencakup kemampuan dasar yang menyeluruh. Tingkat kesulitannya, disesuaikan dengan topic yang berwawasan dunia anak remaja sehingga sangat nyaman untuk dikerjakan.

Sedangkan pada level A/AS Level, tuntutannya sangat tinggi baik dari pengetahuan topik maupun kemahiran bahasa dan menulis yang sangat menuntut ketelitian dan kecermatan. Keahlian yang di uji hanya pada kemampuan membaca dan sebagian besar menulis. Di A/AS Level, siswa sudah harus menguasai tidak saja pengertian ragam register tetapi sudah harus mampu menganalisis dan menggunakan ragam register dalam tulisan. Dengan demikian banyak faktor yang berkaitan dengan penulisan yang harus dikuasai siswa seperti: penguasaan kosa kata yang sesuai, gaya penulisan, struktur bahasa, grammatika, koherensi, kala/tenses dan semua ini mengarah kepada penguasaan kesusastraan dalam bahasa Inggris.

Tingkat kesulitan antara Materi ajar IGCSE dibandingkan dengan A/AS Level berbeda karena IGCSE merujuk pada kemampuan berbahasa secara menyeluruh baik dalam membaca, menulis, mendengar dan berbicara di berbagai situasi dengan pembekalan kosa kata yang memadai. Sehingga siswa akan mampu berkomunikasi dengan baik. Dalam A/AS Level, siswa dituntut untuk tidak hanya mampu berkomunikasi tetapi juga harus mampu menilai, memaknai, berargumentasi, dan berkreasi dalam bentuk tulisan antar 600-900 kata. Karena tuntutan yang berbeda diantara IGCSE dengan A/AS Level maka kesulitan yang timbul sangat terasa bagi siswa yang bahasa Inggris bukan merupakan bahasa ibu atau bahasa kedua mereka.

Di sisi lain, tingkat kemampuan siswa SMA 70, dari hasil tes A/AS Level menyatakan hampir seluruh siswa tidak mampu mengerjakan tes sesuai standar yang ditentukan, kecuali beberapa yang memperlihatkan kecakapan menulis di A/AS Level. Kelemahan dalam menulis dan seluruh aspek yang terkait dengan kebahasaan dan tulisan merupakan masalah besar yang harus di sikapi para pendidik dengan seksama.

Kondisi ini dibebani pula dengan kurikulum yang padat, tetapi tidak dapat memperbaiki tingkat kemahiran siswa secara efektif karena adanya keterbatasan waktu untuk memperdalam materi A/AS Level.

Dengan Demikian saran pertama yang diusulkan adalah menciptakan kurikulum yang efektif dengan memberikan lebih banyak pola pembelajaran Cambridge A/AS Level dikelas $x$, dan $x i$. Kurikulum yang ideal bagi kelas internasional adalah kurikulum Cambridg terutama untuk mata ajar Bahasa Inggris. Kedua, siswa harus diberi pelatihan yang berkesinambungan dalam menulis sehingga waktu yang ideal untuk pelatihan bahasa Inggris menjadi dua kali lebih besar dari yang ada saat ini menjadi 2x 135 menit untuk 2 tahun pembelajaran. Ketiga, berkaitan dengan proses belajar dan mengajar, disamping kemampuan siswa yang harus ditingkatkan, faktor kemampuan pengajar, metodologi pembelajaran yang tepat dan efektif juga harus ditingkatkan berikut pengadaan fasilitas laboratorium dan perpustakaan yang menyediakan beragam buku A/AS Level. Keempat, sekolah harus menjalin kerja sama dengan sekolah lain untuk menghidupkan dan mengikuti perkembangan IGCSE dan A/AS Level. Kelima, Sekolah harus memberi kesempatan bagi siswa untuk mengikuti ujian A/AS Level secara berkala sehingga mereka terbiasa dengan pola pembelajaran Cambridge.

\section{DAFTAR PUSTAKA}

[1] Brown Douglas, Language Assessment- Principle and Classroom Practices San Francisco State university, 2004.

[2] Direktorat Jendral Manajemen Pendidikan Dasar dan Menengah, Pedoman Penjaminan Mutu Sekolah/Madrasah Bertaraf Intenasional Pada Jenjang Pendidikan Dasar dan Menengah, Jakarta, Departemen Pendidikan Nasional, 2008.

[3] Larasen-Freeman, Diane, Techiques and Principles in Language Teaching. Oxford: University Press, 2008.

[4] Oxford, Rebecca L. Language Learning Srategies. Boston: Heinle \& Heinle Publisher, 1990.

[5] Syamsudin- Damaianti, Metode Penelitian Bahasa. Penerbit Rosda, 2006.

[6] www.cie.org.uk/syllabuses for examination in 2009, 2010

[7] www.cie.org.uk/specimen papers and mark scheme

[8] www.cie.org.uk/June and November 2008 past question papers

[9] www.cie.org.uk/June and November 2008 report on examinations

[10] www.cie.org.uk/June and November 2008 published mark schemes 
Jurnal AL-AZHAR INDONESIA SERI HUMANIORA, Vol. 1, No. 1, Maret 2011 